Research Article

\title{
The Impact of Venture Capital on the Growth of Small- and Medium-Sized Enterprises in Agriculture
}

\author{
Junjuan Du $\mathbb{D}^{1}$ and Zheng-Qun Cai $\mathbb{D}^{2}$ \\ ${ }^{1}$ School of Accounting and Finance, Anhui Xinhua University, Hefei 230088, China \\ ${ }^{2}$ School of Foreign Studies, Anhui Jianzhu University, Hefei 230601, China \\ Correspondence should be addressed to Zheng-Qun Cai; caizhengqun1983@163.com
}

Received 8 October 2019; Revised 28 November 2019; Accepted 6 March 2020; Published 30 March 2020

Guest Editor: Shaohui Wang

Copyright (C) 2020 Junjuan Du and Zheng-Qun Cai. This is an open access article distributed under the Creative Commons Attribution License, which permits unrestricted use, distribution, and reproduction in any medium, provided the original work is properly cited.

\begin{abstract}
Small- and medium-sized enterprises (SMEs) are considered to have potential innovation capabilities and can create new market opportunities. Venture capital can financially support entrepreneurial activities for economic growth and governs and nurtures the growth of the SMEs. The aim of this study is to investigate the influence mechanism of venture capital on the development of SMEs in agri-food industry. Based on the enterprise growth theory, this study constructed an evaluation model, consisting of technological innovation, profitability, development capability, and solvency, to examine the effect of venture capital on the growth of agricultural SMEs. Using data of 40 agricultural SEMs from the SME and ChiNext boards in China, the empirical analysis has been conducted with the multivariate regression analysis method. The results show that the venture capital can significantly improve the technology innovation, profitability, and growth ability of SMEs. For the solvency of SMEs, the promoting role of venture capital is not obvious. Finally, the practical implications of this study for venture capitalists, entrepreneurs, and regulators are discussed.
\end{abstract}

\section{Introduction}

Small- and medium-sized enterprises (SMEs) are of great value to the stable and sustainable development of the economy and attracted high attention from governments worldwide. SMEs are viewed as a trigger of innovation and economic development, which can promote economic growth, urbanization, employment, technological innovation, social harmony, and stability. Data collected by Ayyagari et al. from 76 developing and developed countries show that SMEs account for nearly $60 \%$ of manufacturing employment on average [1]. Recently, many policies have been intensively formulated to stimulate the development of SMEs, such as preferential taxation policies in China $[2,3]$. According to data from the National Bureau of Statistics, there are 369,000 SMEs at the end of 2018 in China, accounting for $97.6 \%$ of the total number of industrial enterprises above the designated size. The main business income of SMEs reached 57.9 trillion Yuan, accounting for
$56.7 \%$ of the regular main business income. The total profit of SMEs was 3.4 trillion Yuan, accounting for $51.6 \%$ of the total profits of the enterprises. SMEs play a significant role in contributing to the national goal of wealth creation and making China an industrialized country [4].

The lack of credit is a main constraint inhibiting the growth of SMEs. Due to unreliable security coupled with an unsound system of legislation and management, SMEs cannot get financial support. Financing channels and costs are often listed as one of the most restrictive characteristics of SMEs in the business environment. The lack of access to finance is considered as major constraint by about $30 \%$ of SMEs, which is similar to economic policy uncertainty and corruption [5]. The financing barriers faced by SMEs are always higher than those of lager enterprises, such as high transaction costs, information asymmetry, inferior position in credit filtration, and greater risks in operation. The relative surplus of macro economy has led to the slow growth of SMEs. Difficulties in credit accumulation lead to the lack of 
financing channels for SMEs [6]. Formal financial institutions considered SMEs as highly risky and difficult to survive commercially. Then, many SMEs could not get sufficient loans from banks. Even though some traditional financial institutions are optimistic about the development of SMEs, they are not willing to provide loans to SMEs without effective guaranty. Due to the insufficient provision of financial services to SMEs, financial constraints are likely to affect business creation and improvement of SMEs [7].

Financial support is the cornerstones for rapid growth of SMEs. As one source of nonbank financing, venture capital is quite prevalent in developed financial markets, which provide an initial capital for the development of many large companies, such as FedEx. King pointed out that venture capital firms operate in a rapidly changing environment [8]. Venture capital funds generally invest in those technology-based private firms that are likely to go public or being acquired at a premium within a few years. The entrepreneurs could obtain venture capital financing at different stages, including seed, start-up, expansion, development, or bridge finance. Venture capitalists can provide financial resources, managerial skills, and technical expertise to the investing enterprises through detailed preliminary research [9]. The providers of venture capital would actively take an ownership stake in the business, provide the needed capital, and share the risk when they considered that a business idea is promising. In other words, the venture capital has been another source of finance for SMEs, which has winning but risky business proposals and a shortage of capital. By providing equity capital, venture capital plays an important role in enhancing growth of SMEs [9]. Currently, SMEs receive more serious financing constraints under the background of "state advanced and private retreats" in China, which seriously restrict the development and transformation of enterprises. For SMEs, the first priority is to make full use of venture capital to promote the growth of SMEs.

Based on enterprise growth theory, this study compared the differences in the economic value added between venture-capital-backed and non-venture-capital-backed SMEs. The promoting role of venture capital on the growth of SMEs in agri-food industry is assessed by an evaluation model consisted of technological innovation, profitability, development capability, and solvency. Finally, this study proposed the practical implications for venture capitalists, SMEs owners, and regulators. We make two major contributions to the literature. First, we constructed a research model to conduct a comparative study on the economic value added of venture capital. Second, the empirical study reveals the mechanism of venture capital influencing the growth of SMEs in agri-food industry.

This paper is organized as follows. Section 2 discusses the literature on the impact of venture capital on growth of SMEs and provides hypotheses. Section 3 introduces variables, data, and research model. Section 4 conducts a comparative static analysis on the effects of venture capital on growth of SMEs by using the multivariate regression analysis method. Finally, we present conclusions, implications, and suggestions for future research.

\section{Theory and Hypotheses}

SMEs account for a large share of employment and a large share of enterprises in the private sector, which have played important roles in the development of developing countries, such as driving innovation and competition [10]. There are four type issues affecting the SMEs: poor funding, worst business environment, lack of access to modern technology, and low managerial skills [11]. To promote the growth of SMEs, proper financing of SMEs is essential. By identifying, financially supporting, and cultivating the growing enterprises with entrepreneurial tenacity, venture capital has showed a promoting role in the development of SMEs, which mainly reflect in the improvement of technological innovation, profitability, development capability, and solvency.

\subsection{Impact of Venture Capital on the Technological Innovation} Ability of SMEs. One of the inherent pursuits of venture capital is to obtain high returns. The improvement in technological innovation can enhance productivity and profit of SMEs, which help to achieve the investment objectives of venture capital. Ueda and Hirukawa revealed that venture capital has significant positive effect on the number of patents [12]. Venckuviene and Saboniene pointed out that the value-added services of venture capital can improve the innovation capabilities of enterprises [13]. Wang found that there is a significant positive correlation between venture capital and technological innovation, which vary among different regions in China [14]. Previous studies indicated that venture capital can provide substantial financial support for technological innovation of SMEs. Based on the discussion of this section, we propose the following hypothesis:

(i) H1a: SMEs with the participation of venture capital have better technological innovation capacities than those without the participation of venture capital

(ii) H1b: venture capital has a positive effect on the improvement of technological innovation capacity of SMEs

\subsection{Impact of Venture Capital on the Profitability of SMEs.} Profitability is an important indicator to evaluate the development of SMEs, which is also a growing concern for venture capitalists. Chahine et al. found that enterprises supported by venture capital have good profitability and market performance [15]. Audretsch and Lehmann proposed that venture capital has a positive effect on enterprise performance, which is complementary to bank loans [16]. Sun suggested that enterprises supported by venture capital have good performance in the first year after initial public offering, which is better than those of enterprises without venture capital [17]. On the contrary, other researchers concluded that venture capital has a nonpositive effect on enterprise performance. For SMEs, the introduction of venture capital can raise the urgently needed capital for promoting the development and improving the performance of enterprises. By raising the share of capital, venture capitalists can exert more influences on the management of 
SMEs and obtain better returns. Therefore, based on the above discussion, the following hypotheses have been put forward:

(i) H2a: SMEs with the participation of venture capital have higher profitability level than those without the participation of venture capital

(ii) H2b: venture capital has a positive effect on the improvement of profitability level of SMEs

\subsection{Impact of Venture Capital on the Development Capability} of SMEs. When selecting investment object, the potential growth of enterprises is the focus of venture capitalists. With the support of venture capital, the development capability of SEMs can be greatly improved. Davila et al. suggested that the most attractive enterprises to venture capital are SMEs with good development prospects [18]. These enterprises can attract outstanding talents and high-tech to prompt the growth of enterprises. From the perspective of value-added services, Chemmanur and Loutskina proved that excellent venture capital can bring first-class brokers and institutional investors to enterprises, which plays a positive role in promoting the development of enterprises [19]. Rosenbusch et al. confirmed that venture capital has a significantly positive impact on the growth ability of enterprises [20]. According to the above analyses, the following hypotheses have been introduced:

(i) H3a: SMEs with the participation of venture capital have higher development capability than those without the participation of venture capital

(ii) H3b: venture capital has a positive effect on the improvement of development capability of SMEs

2.4. Impact of Venture Capital on the Solvency of SMEs. When investing, venture capitalist can provide intellectual capital, professional relationships, management guidance, business development, and business model consulting for SMEs. Jain and Kini found that there is an increase in sales volume and sales growth rate for SMEs with venture capital after being listed [21]. Nahata concluded that venture capital with higher reputation can significantly improve the solvency of SMEs [22]. Chaopeng et al. confirmed that venture capital can suppress excessive investment of the enterprise in free cash, enlarge short-term debt and equity financing, and alleviate the shortage of cash flow to a certain extent [23]. For SMEs with poor solvency, the introduction of venture capital can drive other social capital to invest in enterprises. The following hypotheses have been put forward according to the above-mentioned analyses:

(i) H4a: SMEs with the participation of venture capital have higher solvency than those without the participation of venture capital

(ii) H4b: venture capital has a positive effect on the improvement of solvency of SMEs

From enterprise growth theory, the enterprise growth can be defined as a process in which enterprises grow from small to large and from weak to strong and constantly realize scale expansion in market competition. The scale expansion includes output scale expansion, input scale expansion, profit scale expansion, and value scale expansion. In this study, we selected four indicators, including technological innovation ability, enterprise profitability, enterprise development ability, and enterprise solvency ability, to measure the growth of enterprises, especially for SMEs. The influences of venture capital on the growth of SMEs are conducted from the two perspectives of the context of venture and the degree of participation of venture capital. To reflect the effect of environmental factors, the control variables are introduced into the empirical process. The research conceptual model in this paper has been constructed, as shown in Figure 1.

\section{Data and Methodology}

3.1. Data. Data for this study were derived from 40 agricultural SMEs on the SME and ChiNext boards in China by the end of 2018. In view of complexity of data and samples of discrete, the data on investment time of venture capital, institutional background, and financial status are all from the prospectuses and listing financial reports of GEM companies. Other data that cannot be directly collected are obtained by calculation. Referring to the method adopted by Chaopeng et al. [23], the SMEs that meet the following criteria are considered to have venture capital background: the names of top 10 major shareholders including "entrepreneurship investment," "venture capital," and "science and technology investment," or a venture capital share of more than $5 \%$. According to this criterion, the selected 40 SMEs were divided into two categories: 20 SMEs with the context of venture capital and 20 SMEs without the context of venture capital.

3.2. Methodology. Using the multivariate regression analysis method, this paper studies the promoting role of venture capital on the growth of SMEs in agriculture. Table 1 displays the descriptions of the variables. Among dependent variables, the technological innovation ability of SMEs is reflected by the variables $R \& D$ investment intensity $(R D I N V)$. The profitability of SMEs is reflected by the operating profit margin (OPGR) and the rate of return on net assets (NAIR). To evaluate the development ability of SMEs, we choose two variables of the operating income growth rate $(O I G R)$ and the growth rate of total assets (TAGR). Finally, the solvency of SMEs is reflected by the cash flow ratio $(C A S H C L)$ and the current ratio $(C R)$. The independent variables are a mix of categorical and continuous variables. The independent variable is represented by DumVC, DumVC1, DumVC2, DumVC3, and DumVC4. Among independent variables, the variable DumVC reflects the context of venture capital and the variables DumVC1, DumVC2, DumVC3, and DumVC4 reflect the degree of participation of venture capital in SMEs. In addition, we take into account the influence of enterprise's own 


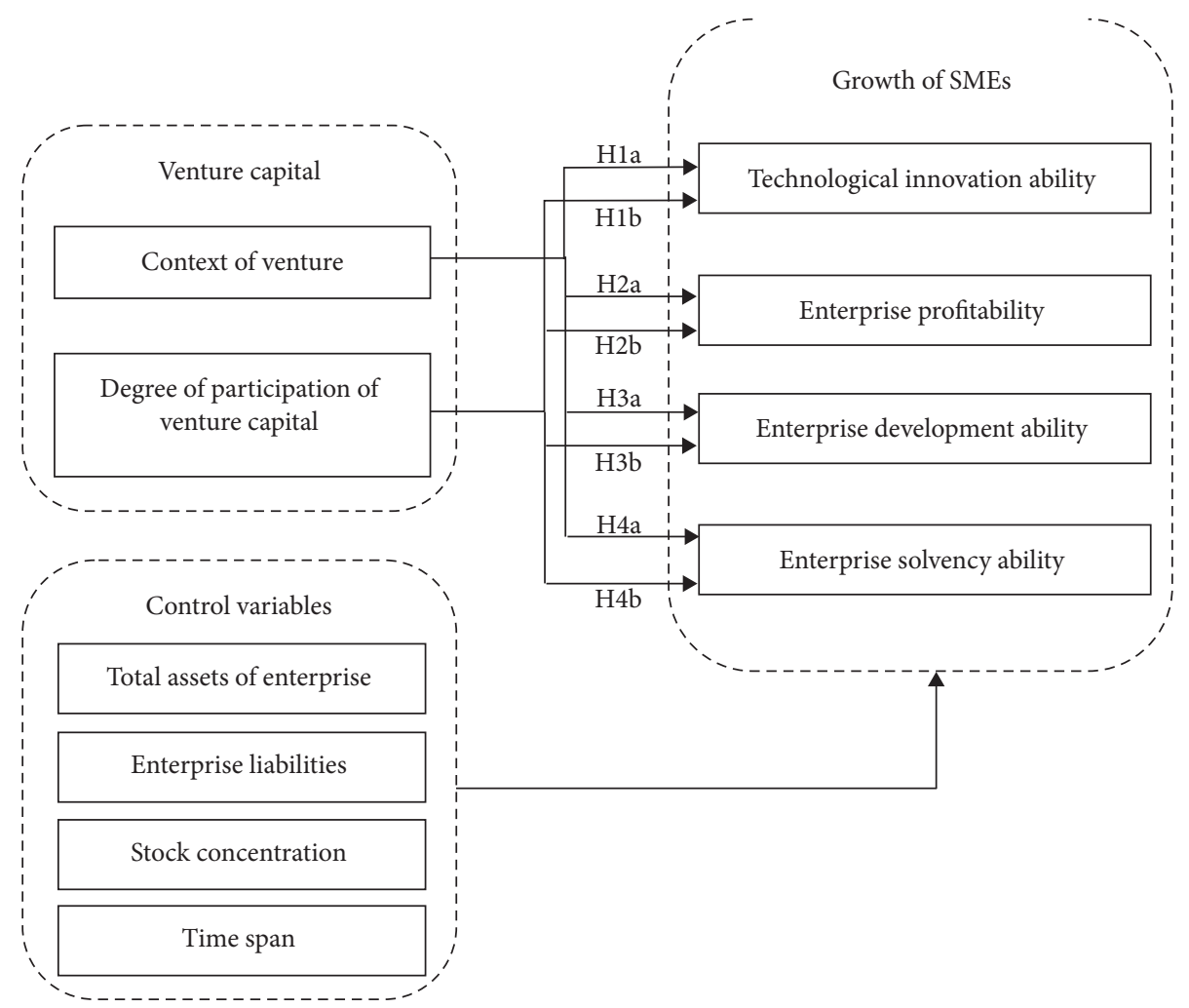

Figure 1: The research conceptual model.

TABLE 1: Description of variables and values assigned.

\begin{tabular}{|c|c|c|c|}
\hline Variables & & Symbol & Description \\
\hline \multirow{7}{*}{$\begin{array}{l}\text { Dependent } \\
\text { variables }\end{array}$} & R\&D investment intensity & $R D I N V$ & $\begin{array}{c}\text { Expenditures by a firm on its research and development divided by the firm's } \\
\text { sales. }\end{array}$ \\
\hline & Operating profit margin & $O P G R$ & It is calculated by dividing the operating profit by total revenue. \\
\hline & Rate of return on net assets & NAIR & A ratio of net income to the average total assets. \\
\hline & $\begin{array}{l}\text { Operating income growth } \\
\text { rate }\end{array}$ & OIGR & $\begin{array}{c}\text { Ratio of increase in operating revenue of current period to prior current } \\
\text { period. }\end{array}$ \\
\hline & Growth rate of total assets & TAGR & Ratio of increase in total assets to total assets. \\
\hline & Cash flow ratio & CASHCL & Ratio of net cash flow from operating activities to incur debts. \\
\hline & & $C R$ & Ratio of current assets to current liabilities. \\
\hline \multirow{5}{*}{$\begin{array}{l}\text { Independent } \\
\text { variables }\end{array}$} & Context of venture capital & DumVC & $\begin{array}{c}\text { Dum } V C=1 \text { if the names of top } 10 \text { shareholders including "entrepreneurship } \\
\text { investment," "venture capital," and "science and technology investment," or a } \\
\text { venture capital share of more than } 5 \% \text {, otherwise } 0 .\end{array}$ \\
\hline & & DumVC1 & $\begin{array}{c}\text { DumVC1 }=1 \text { if the share ratio of venture capital ranges between } 5 \% \text { and } 15 \% \\
\text { (inclusive of } 5 \% \text { and } 15 \% \text { ), otherwise } 0 .\end{array}$ \\
\hline & Degree of participation of & DumVC2 & $\begin{array}{c}\text { DumVC2 }=1 \text { if the share ratio of venture capital ranges between } 15 \% \text { and } 25 \% \\
\text { (inclusive of } 25 \% \text { ), otherwise } 0 .\end{array}$ \\
\hline & & DumVC3 & $\begin{array}{c}\text { DumVC3 }=1 \text { if the share ratio of the venture capital ranges between } 25 \% \text { and } \\
35 \% \text { (inclusive of } 35 \% \text { ), otherwise } 0 .\end{array}$ \\
\hline & & DumVC4 & DumVC2 $=1$ if the share ratio of venture capital is greater than $35 \%$, otherwise 0 . \\
\hline \multirow{4}{*}{ Control variables } & Total assets & $T A$ & Total assets of enterprise. \\
\hline & Enterprise liabilities & $A L R$ & al liabiliti \\
\hline & Ownership structure & Zindex & $\begin{array}{l}\text { Ratio of the percentage of the first major stockholder to the percentage of the } \\
\text { second major stockholder. }\end{array}$ \\
\hline & Time span & Time & Time it takes for a SME to go IPOs from start-ups. \\
\hline
\end{tabular}

characteristics on the relation between venture capital and the growth of SMEs. Control variables, including TA, $A L R$, Zindex, and Time, are selected to evaluate this impact of enterprise's own characteristics.
3.3. Model. To test our hypotheses related to the effects of venture capital on the growth of SMEs, the multiple linear regression models are constructed. These models are expressed by 


$$
\begin{aligned}
y_{i}=\alpha_{0 i} & +\alpha_{1 i} \text { DumVC }+\alpha_{2 i} T A+\alpha_{3 i} A L R \\
& +\alpha_{4 i} \text { Zindex }+\alpha_{5 i} \text { Time }+\varepsilon_{i}, \\
y_{i}=\beta_{0 i} & +\beta_{1 i} \text { DumVC } 1+\beta_{2 i} \text { DumVC2 }+\beta_{3 i} \text { DumVC } 3 \\
& +\beta_{4 i} \text { DumVC } 4+\beta_{5 i} T A+\beta_{6 i} A L R \\
& +\beta_{7 i} \text { Zindex }+\beta_{8 i} \text { Time }+\varepsilon_{i},
\end{aligned}
$$

where $y(i=1,2, \ldots, 7)$ represents the dependent variables, including $\mathrm{R} \& \mathrm{D}$ input intensity, operating profit margin, rate of return on net assets, operating income growth rate, growth rate of total assets, cash flow ratio, and current ratio; $\alpha_{0}, \beta_{0}$, and $\lambda_{0}$ are the intercept of models; $\alpha_{i}(i=1,2, \ldots, 12)$ and $\beta_{i}(i=1,2, \ldots, 12)$ are the coefficients of models; and $\varepsilon_{i}$ are the random error terms.

\section{Results}

4.1. Descriptive Statistics. The statistical results show that venture capitalist prefers to invest in SMEs which have relatively stable income. The shareholding ratio of venture capital has influences on the operation of SMEs. The rational shareholding ratio of venture capital can effectively improve the technological innovation and the operating performance of SMEs. Ruhnka and Young proposed that the optimum share ratio of venture capital in SMEs is 30\% [24]. Currently, the share ratio of venture capital of $65 \%$ SMEs in China is less than 25\%. Meanwhile, the venture capitalists prefer a long-established company. The data show that $80 \%$ SMEs without venture capital have less than 10 years from establishment to listing. Correspondingly, 55\% of SMEs with venture capital context took more than 10 years to listing. Figure 2 shows the distribution of the dependant variables and control variables of all collected sample enterprises. Compared to SMEs without venture capital, SMEs with venture capital have better performances in terms of technological innovation investment intensity, operating profit margin, return on net assets, operating income growth rate, growth rate of total assets, cash flow ratio, and current ratio. To ensure investment income, venture capitalists tend to invest in a large-scale, long-established, low-leverage, and high-return SME in the agri-food industry.

4.2. Regression Analysis and Hypothesis Testing. Using SPSS 21, the Pearson correlation test is performed. The results indicate that the pairwise correlation between the variables is weak (the Pearson correlation coefficients are less than 0.5 ). The variance inflation factors of all variables are less than 2 , which reveal that the effect of multicollinearity among variables is not significant. In addition to categorical variables and ordinal variables, other variables are processed by multiple regressions after logarithmic treatment. The regression results are shown in Table 2-5, respectively.

As shown in Table 2, the coefficient of DumVC in model 1 is 0.012 , which indicates the significantly positive influence of venture capital on R\&D investment intensity (RDINV) at the level of $1 \%$. Meanwhile, the total assets (TA) show a positive correlation with $\mathrm{R} \& \mathrm{D}$ investment intensity $(R D I N V)$, and the enterprise liabilities $(A L R)$ have a negative effect on R\&D investment intensity ( $R D I N V)$. The regression results show that the scale of technological innovation investment of SMEs with venture capital is more than that of SMEs without venture capital. Large enterprises can provide more capital for technological innovation. The improvement of enterprise's sustainable development ability can bring generous returns to venture capitalists, thus supporting $\mathrm{H} 1 \mathrm{a}$. The variables of share ratio of venture capital, including DumVC1, DumVC2, DumVC3, and DumVC4, have different influences on $\mathrm{R} \& \mathrm{D}$ investment intensity (RDINV). The share ratio of venture capital has a positive influence on $R \& D$ expenditure of SMEs, which supports hypothesis H1b.

Table 3 shows the regression results of effects of venture capital on profitability of SMEs. The coefficients between venture capital and dependant variables (OPGR and NAIR) are 0.022 and 0.126 respectively, which support hypothesis $\mathrm{H} 2 \mathrm{a}$. The regression results of the shareholding ratio of venture capital (including DumVC1, DumVC2, DumVC3, and DumVC4) on operating profit margin (OPGR) show that DumVC1 has no influence on OPGR, and the coefficients of DumVC2, DumVC3, and DumVC4 on OPGR are $0.05,0.049$, and 0.086 at the level of $5 \%$, respectively. The coefficients of Dum VC1, Dum VC2, DumVC3, and DumVC4 on profit margin of net assets (NAIR) are 0.098, 0.151, 0.213, and 0.31 at the level of $1 \%$, respectively. Hypothesis $\mathrm{H} 2 \mathrm{~b}$ is supported. The results illustrate that the influences of venture capital institutions on SMEs management can improve the operation efficiency of assets and optimize the capital structure of the invested SMEs. Increasing the shareholding ratio of venture capital can strengthen SMEs' adaptability to market changes and competitiveness, improve the profitability, and obtain high returns.

The regression results of venture capital on development ability of SMEs are shown in Table 4 . In model 1, the regression coefficients of venture capital background (DumVC) on the operating income growth rate (OIGR) and the growth rate of total assets $(T A G R)$ are 0.199 and 0.438 , respectively, which prove the role of venture capital on the growth ability of SMEs and support hypothesis $\mathrm{H} 3 \mathrm{a}$. In terms of the influences of shareholding ratio of venture capital on development ability of SMEs, the regression results show that only DumVC4 is correlated with the operating income growth rate (OIGR) and the growth rate of total assets $(T A G R)$. The coefficients are 0.721 and 1.045 at the level of $1 \%$, respectively, thereby supporting H3b. The improvement of the shareholding ratio can enhance the influence of venture capital institutions on SMEs' decisionmaking and management and promote the ability of enterprise resources integration and the development of SMEs. The SMEs are successfully listed with the assistance of venture capitalists, who will withdraw from the enterprises after obtaining the final income.

The regression results in Table 5 show that the venture capital has no correlation with the cash flow rate (CASHCL). The share ratio of venture capital (including DumVC, DumVC1, DumVC2, DumVC3 and DumVC4) has positive effects on the current ratio $(C R)$ at the level of $10 \%$. The 


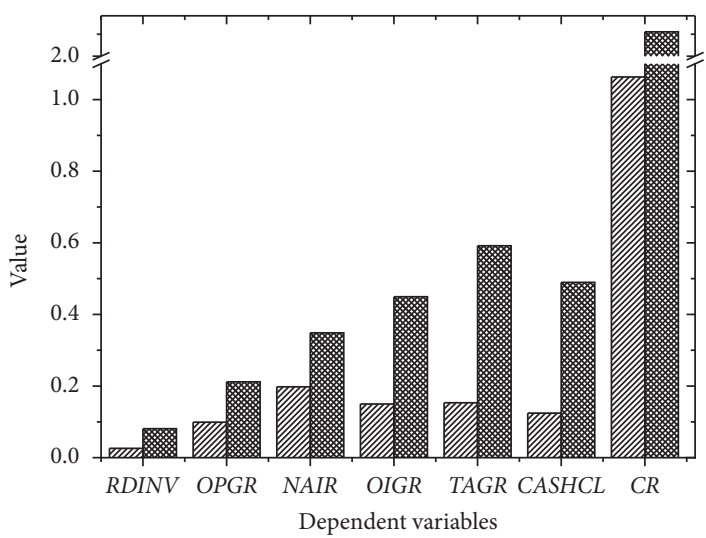

Without participation of venture capital With participation of venture capital

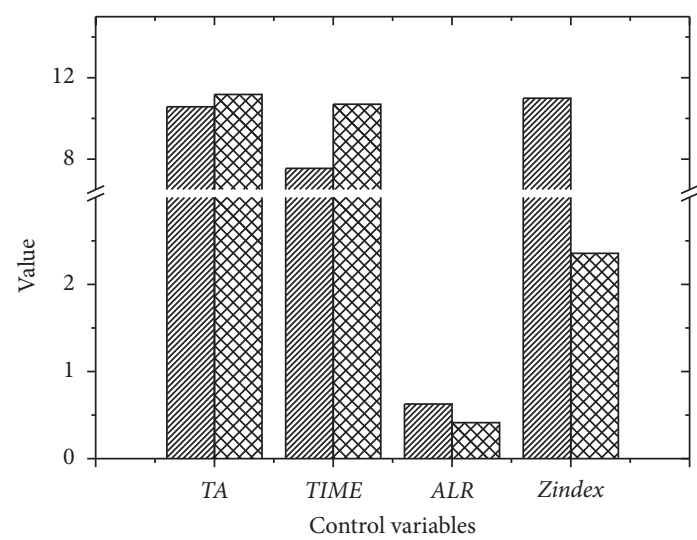

Without participation of venture capital

With participation of venture capital

FIgURE 2: The mean value comparisons of development indicators of SMEs with or without venture capital.

TABLE 2: Effects of venture capital on the technological innovation of SMEs.

\begin{tabular}{lcc}
\hline Dependant variable & Model 1 & RDINV \\
\hline Constant & $0.038^{* * *}(0.565)$ & $-0.033^{* * *}(-0.523)$ \\
DumVC & $0.012^{* * *}(2.025)$ & - \\
DumVC1 & - & - \\
DumVC2 & - & $0.026^{* * *}(3.195)$ \\
DumVC3 & - & $0.049^{* * *}(5.008)$ \\
DumVC4 & $0.009^{*}(1.771)$ & $0.051^{* * *}(6.500)$ \\
TA & - & $0.011^{*}(2.550)$ \\
Time & $-0.175^{*}(-6.923)$ & - \\
ALR & - & $-0.099^{*}(-3.601)$ \\
Zindex & $106.080^{* * *}$ & - \\
F value & 0.890 & $138.264^{* * *}$ \\
Adjusted $R^{2}$ & & 0.946 \\
\hline
\end{tabular}

Note. ${ }^{*} p<0.1 ;{ }^{* *} p<0.05 ;{ }^{* * *} p<0.01$. Source: authors' elaboration.

TABLE 3: Effects of venture capital on the profitability of SMEs.

\begin{tabular}{|c|c|c|c|c|}
\hline \multirow{2}{*}{ Dependant variable } & \multicolumn{2}{|c|}{ OPGR } & \multicolumn{2}{|c|}{ NAIR } \\
\hline & Model 1 & Model 2 & Model 1 & Model 2 \\
\hline Constant & $0.038^{* *}(0.265)$ & $-0.117^{* *}(-0.726)$ & $0.324^{* * *}(6.617)$ & $0.163^{* * *}(9.357)$ \\
\hline$D u m V C$ & $0.022^{* * *}(1.782)$ & - & $0.126^{* * *}(4.411)$ & - \\
\hline DumVC1 & - & - & - & $0.098^{* * *}(3.994)$ \\
\hline DumVC2 & - & $0.05^{* * *}(2.378)$ & - & $0.151^{* * *}(5.798)$ \\
\hline DumVC3 & - & $0.049^{* * *}(1.928)$ & - & $0.213^{* * *}(5.349)$ \\
\hline DumVC4 & - & $0.086^{* * *}(4.232)$ & - & $0.31^{* * *}(10.975)$ \\
\hline$T A$ & $0.026^{* *}(2.449)$ & $0.034^{* *}(2.896)$ & - & - \\
\hline Time & - & - & - & - \\
\hline$A L R$ & $-0.348^{* *}(-6.616)$ & $-0.220^{*}(-3.100)$ & $-0.269^{*}(-3.572)$ & \\
\hline Zindex & - & - & $0.004^{* *}(2.407)$ & $0.003^{* *}(2.716)$ \\
\hline$F$ value & $108.643^{* * *}$ & $89.574^{* * *}$ & $21.273^{* * *}$ & $28.325^{* * *}$ \\
\hline Adjusted $R^{2}$ & 0.892 & 0.919 & 0.609 & 0.778 \\
\hline
\end{tabular}

Note. ${ }^{*} p<0.1 ;{ }^{* *} p<0.05 ;{ }^{* * *} p<0.01$. Source: authors' elaboration. 
TABLE 4: Effect of venture capital on the development ability of SMEs.

\begin{tabular}{|c|c|c|c|c|}
\hline \multirow{2}{*}{ Dependent variable } & \multicolumn{2}{|c|}{ OIGR } & \multicolumn{2}{|c|}{ TAGR } \\
\hline & Model 1 & Model 2 & Model 1 & Model 2 \\
\hline Constant & $-1.594^{* *}(-2.033)$ & $0.209^{* * *}(4.171)$ & $0.153^{* *}(1.527)$ & $0.242^{* * *}(4.023)$ \\
\hline DumVC & $0.199^{* *}(1.729)$ & & $0.438^{* *}(3.088)$ & \\
\hline DumVC1 & - & - & - & - \\
\hline DumVC2 & - & - & - & - \\
\hline DumVC3 & - & - & - & - \\
\hline DumVC4 & - & $0.721^{* * *}(5.079)$ & & $1.045^{* * *}(6.143)$ \\
\hline$T A$ & $0.165^{*}(2.235)$ & - & - & - \\
\hline Time & - & - & - & - \\
\hline$A L R$ & - & - & - & - \\
\hline Zindex & - & - & - & - \\
\hline$F$ value & $6.480^{* * *}$ & $25.793^{* * *}$ & $9.536^{* * *}$ & $37.733^{* * *}$ \\
\hline Adjusted $R^{2}$ & 0.219 & 0.389 & 0.180 & 0.485 \\
\hline
\end{tabular}

Note. ${ }^{*} p<0.1 ;{ }^{* *} p<0.05 ;{ }^{* * *} p<0.01$. Source: authors' elaboration.

TABLE 5: Effect of venture capital on the solvency of SMEs.

\begin{tabular}{|c|c|c|c|c|}
\hline \multirow{2}{*}{ Dependant variable } & \multicolumn{2}{|c|}{ CASHCL } & \multicolumn{2}{|c|}{$C R$} \\
\hline & Model 1 & Model 2 & Model 1 & Model 2 \\
\hline Constant & $1.112^{* * *}(16.538)$ & $1.112^{* * *}(16.538)$ & $2.444^{* * *}(5.621)$ & $1.201^{* * *}(11.579)$ \\
\hline DumVC & - & - & $0.743^{*}(3.094)$ & \\
\hline DumVC1 & - & - & - & $0.386^{*}(2.640)$ \\
\hline DumVC2 & - & - & - & $0.741^{*}(4.762)$ \\
\hline DumVC3 & - & - & - & $1.21^{*}(5.088)$ \\
\hline DumVC4 & - & - & - & $2.514^{*}(14.912)$ \\
\hline$T A$ & - & - & - & - \\
\hline Time & - & - & - & - \\
\hline$A L R$ & $-1.548^{* *}(-12.691)$ & $-1.548^{* *}(-12.691)$ & $-2.199^{*}(-3.347)$ & - \\
\hline Zindex & - & - & - & $-0.013^{*}(-1.775)$ \\
\hline$F$ value & $161.055^{* * *}$ & $161.055^{* * *}$ & $25.148^{* * *}$ & $62.545^{* * *}$ \\
\hline Adjusted $R^{2}$ & 0.804 & 0.804 & 0.553 & 0.888 \\
\hline
\end{tabular}

Note. ${ }^{*} p<0.1 ;{ }^{* *} p<0.05 ;{ }^{* * *} p<0.01$. Source: authors' elaboration.

hypotheses $\mathrm{H} 4 \mathrm{a}$ and $\mathrm{H} 4 \mathrm{~b}$ are partially supported. The venture capitalists in China are intended to invest the SMEs with guaranteed income, low current rate, and high solvency.

\section{Conclusions and Implications}

5.1. Conclusions. This review created an evaluation model to investigate the impact of venture capital and the share ratio of venture capital on the growth of SMEs in agriculture based on enterprise growth theory. These findings can help the entrepreneurs of SMEs set a reasonable development plan to attract venture capital. We found that the venture capital in China has its own characteristics in selecting investee and promoting the development of SMEs. First, the venture capitalists prefer to invest in largescale SMEs with stable operation, low debt ratio, low ownership concentration, and stable returns. Second, the venture capital can improve the technological innovation, the profitability, and the development ability of SMEs. Third, the venture capital has no significant impact on the solvency of SMEs.
5.2. Implications. This study sought to further develop enterprise growth theory. It provides theoretical basis and practical reference for encouraging venture capital to invest in SMEs, solving the financing constraints on SMEs, and improving the growth of SMEs. From a practical perspective, this study provides some suggestions for SMEs in China who want to obtain financial support from venture capital for their own growth. First, the entrepreneurs should formulate a scientific and standardized management system and establish an internal organization with clear responsibility in SMEs, based on the concept of modern corporate governance. Under the premise of protecting their own rights and interests, the entrepreneurs should increase the share of venture capitalists in the business income to attract the investment of venture capital. In addition, some measurements should be adopted to encourage the venture capitalists to participate in the management of SMEs, so as to improve the value-added service level of venture capital. Second, the venture capitalists should actively learn some Chinese laws about financial investment, enterprise management, and operation and fully understand the huge development potential of 
SMEs in China. Setting a reasonable investment plan of venture capital is necessary for supporting the rapid growth of SMEs in technology, management, etc. Third, the regulators should set perfect financing policy and scientific credit supervision mechanism to guarantee revenue for venture capitalists. A series of preferential policies, such as investment subsidies, price subsidies, tax credit, and R\&D supports, should be adopted to improve the profitability of SMEs and the investment income of venture capital. A seed fund with government capital as the main body should be established to introduce venture capital into the high-risk and high-yield SMEs.

\section{Data Availability}

All data generated or analyzed during this study are included in this published article and are available upon request from the corresponding author.

\section{Conflicts of Interest}

The authors declare that there are no conflicts of interest.

\section{Acknowledgments}

This study was supported by the Foundation for Planning of Philosophy and Social Sciences of Anhui Province (Award Number: AHSKF2018D62). Gratitude is also extended to all authors of the literature cited by this article.

\section{References}

[1] M. Ayyagari, T. Beck, and A. Demirguc-Kunt, "Small and medium enterprises across the globe," Small Business Economics, vol. 29, no. 4, pp. 415-434, 2007.

[2] Y. Zhu, X. Wittmann, and M. W. Peng, "Institution-based barriers to innovation in SMEs in China," Asia Pacific Journal of Management, vol. 29, no. 4, pp. 1131-1142, 2012.

[3] T. George, "Fair competition and preferential taxation policy for small \& medium retail stores in China: a comparative study," Journal of Chinese Tax and Policy, vol. 3, no. 3, pp. 140-164, 2013.

[4] J. Yu and J. N. B. Bell, "Building a sustainable business in china's small and medium-sized enterprises (SMEs)," Journal of Environmental Assessment Policy and Management, vol. 9, no. 1, pp. 19-43, 2007.

[5] F. Olawale and D. Garwe, "Obstacles to the growth of new SMEs in South Africa: a principal component analysis approach," African Journal of Business Management, vol. 4, no. 5, pp. 729-738, 2010.

[6] J. Jiang, Z. Li, and C. Lin, "Financing difficulties of SMEs from its financing sources in China," Journal of Service Science and Management, vol. 7, no. 3, pp. 196-200, 2014.

[7] S. F. Memba, W. R. Gakure, and K. Karanja, "Venture capital (VC): its impact on growth of small and medium enterprises in Kenya," International Journal of Business and Social Science, vol. 3, no. 6, pp. 32-38, 2012.

[8] B. L. King, "Strategizing at leading venture capital firms: of planning, opportunism and deliberate emergence," Long Range Planning, vol. 41, no. 3, pp. 345-366, 2008.

[9] A. A. Eniola, "The role of SME firm performance in Nigeria," Oman Chapter of Arabian Jou 10.12816/0016552 rnal of
Business and Management Review, vol. 3, no. 12, pp. 33-47, 2014.

[10] R. U. Etuk, G. R. Etuk, and B. Michael, "Small and medium scale enterprises (SMEs) and Nigeria's economic development," Mediterranean Journal of Social Sciences, vol. 5, no. 7, pp. 656-662, 2014.

[11] O. O. Fatoki, A. Van, and A. Smit, "Constraints to credit access by new SMEs in South Africa: a supply-side analysis," African Journal of Business Management, vol. 5, no. 4, pp. 1413-1425, 2011.

[12] M. Ueda and M. Hirukawa, "Venture capital and industrial innovation," SSRN Electronic Journal, vol. 2008, 2008.

[13] V. Venckuviene and A. Saboniene, "Implications for mitigating human resource and labor market restriction in lowtech sector," Procedia-Social and Behavioral Sciences, vol. 213, pp. 192-197, 2015.

[14] T. Wang, "Effect of VC to technology innovation based on regional perspective," Studies in Science of Science, vol. 34, no. 10, pp. 1576-1582, 2016, in Chinese.

[15] S. Chahine, J. D. Arthurs, I. Filatotchev, and R. E. Hoskisson, "The effects of venture capital syndicate diversity on earnings management and performance of IPOs in the US and UK: an institutional perspective," Journal of Corporate Finance, vol. 18, no. 1, pp. 179-192, 2012.

[16] D. B. Audretsch and E. E. Lehmann, "Financing high-tech growth: the role of banks and venture capitalists," Schmalenbach Business Review, vol. 56, no. 4, pp. 340-357, 2004.

[17] J. h. Sun, "Empirical support of decline in enterprises' operating performance after the IPO from the perspective of venture capital," Finance \& Economics, vol. 8, pp. 67-78, 2015, in Chinese.

[18] A. Davila, G. Foster, and M. Gupta, "Venture capital financing and the growth of startup firms," Journal of Business Venturing, vol. 18, no. 6, pp. 689-708, 2003.

[19] T. J. Chemmanur and E. Loutskina, "The role of venture capital backing in initial public offerings: certification, screening, or market power?" in Proceedings of the EFA 2005 Moscow Meetings, Moscow, Russia, September 2006.

[20] N. Rosenbusch, J. Brinckmann, and V. Müller, "Does acquiring venture capital pay off for the funded firms? a metaanalysis on the relationship between venture capital investment and funded firm financial performance," Journal of Business Venturing, vol. 28, no. 3, pp. 335-353, 2013.

[21] B. A. Jain and O. Kini, "Venture capitalist participation and the post-issue operating performance of IPO firms," Managerial and Decision Economics, vol. 16, no. 6, pp. 593-606, 1995.

[22] R. Nahata, "Venture capital reputation and investment performances," Journal of Financial Economics, vol. 90, no. 2, pp. 127-151, 2008.

[23] W. Chaopeng, W. Shinong, C. Jingya, and W. Lu, "The role of venture capital in the investment and financing behavior of listed companies: evidence from China," Economic Research Journal, vol. 1, pp. 105-119, 2012, in Chinese.

[24] J. C. Ruhnka and J. E. Young, "Some hypotheses about risk in venture capital investing," Journal of Business Venturing, vol. 6, no. 2, pp. 115-133, 1991. 